PUBLIC HEALTH POLICY AND PRACTICE

\title{
Origins and early history of the Society for Social Medicine in the UK and Ireland
}

\section{J Pemberton}

J Epidemiol Community Health 2002;56:342-346

This is a personal account of my recollections of the origins and early history of the Society for Social Medicine. Others may have different views of the significance of the events described or of the contributions of those concerned with its beginnings.

\section{NEGLECT OF SOCIAL FACTORS IN TRAINING OF DOCTORS IN THE 1930s}

The term social medicine was almost unknown to those of us who qualified in the UK before the second world war. It had, however, been used earlier in a few European medical schools. For example, Andrija Stampar,* later to become one of the founders of the World Health Organisation, had been appointed Professor of Social Medicine in Zagreb University in 1931.

In British medical schools at this time there were courses of lectures in public health, usually given by a local medical officer of health. They concentrated on the detailed law relating to sanitation, the epidemiology of infectious diseases, and the administration of health services provided by the local health authorities. As medical students, we found these lectures tedious and not relevant to the diseases we were studying in the hospital wards. We knew little about the work of the $\mathrm{MOH}$, and he had nothing like the influence on us of the consultant physicians and surgeons of the teaching hospitals, the "honoraries", whom we admired and held in awe.

The imbalance in the training of medical students in the 1930s, especially in the clinical years, can be largely attributed to the domination of the clinical curriculum by the teaching hospital consultants whose incomes depended on private practice and who determined the types of patient admitted to the teaching hospitals. These consisted mainly of patients with heart, digestive and respiratory disease (other than tuberculosis), cancer, neurological disease (usually untreatable and incurable), metabolic and blood disorders, and all types of surgery and trauma. In none of these did social factors in prevention or treatment seem important at that time and these aspects were rarely, if ever, discussed by our teachers. Patients suffering from any of the following groups of diseases, in which social factors were, and still are, of great importance, were not normally admitted to teaching hospitals: mental illness, infectious fevers, sexually transmitted disease (except late syphilis), and tuberculosis.

In the year I qualified, 1936, there were 26268 deaths from tuberculosis in England and Wales.

In a decade in which the number of unemployed exceeded three million, when out of work men took part in "hunger marches" from the north of England to the Houses of Parliament carrying banners saying "We march against starvation" it is remarkable that the medical profession, with a few exceptions, was not more concerned about the effects of poverty on health. John (later Lord) Boyd Orr was one doctor who was concerned and who made his voice heard on the radio and in his classic book Food, Health and Income published in 1936. ${ }^{1}$ In this he reported a survey that showed that a large proportion of the population was not getting enough food for health and growth. Another distinguished doctor, James Spence (later Sir James and professor of Child Health in Newcastle University), had shown in 1934 that the children he saw as private patients were taller and heavier and had higher concentrations of haemoglobin in their blood than those he saw in hospital outpatients. ${ }^{2}$

\section{TWO MEDICAL-POLITICAL ORGANISATIONS THAT PROMOTED SOCIAL MEDICINE IN THE 1930S}

The Committee against Malnutrition, organised by F Le Gros Clark, was an influential medicalpolitical body that arranged public meetings in the late 1930s and raised public awareness of the harmful effects on health of the widespread malnutrition at the time. The committee was supported by some distinguished doctors, including Dr Janet Vaughan and Professors V H Mottram and F R Marrack. ${ }^{3}$

The Socialist Medical Association (SMA), founded by a few doctors in 1930, was another medical-political group whose members recognised the close relation between poverty and ill health and the importance of political decisions for changing these conditions. The SMA promoted, within the Labour party, the idea of a comprehensive health service, free at the time of use. It was responsible for much of the thinking underlying the National Health Service, which was introduced by the Labour government in 1948. Several members of the SMA later became founder members of the Society for Social Medicine, including Richard Doll, Horace Joules, and myself. A detailed history of the Socialist Medicine Association has been published by Stewart. ${ }^{4}$

My own interest in the social and political aspects of medicine had been aroused in the early

* Stampar was a survivor of several regimes and a big man in every way. He started a lecture to the Sheffield medical school with the words: "I expect that I am the only professor of social medicine who has been in prison four times." 
1930s when, as a third year student, I had joined a group of fellow students to meet the unemployed Jarrow marchers when they came to London to present a petition to parliament. We dressed the blisters on their feet and later joined them as they marched up Whitehall to present their petition. We were met by a charge of mounted police brandishing batons before whom we rapidly retreated.

\section{THE DEVELOPMENT OF ACADEMIC SOCIAL MEDICINE}

The appointment by Oxford University of John Ryle, professor of physic at Cambridge and consultant physician at Guy's Hospital, to the first chair of social medicine in the UK, in 1942 provided a great stimulus to social medicine as an academic discipline. Ryle put forward the idea that certain population groups were prone to certain diseases because of the conditions under which they lived. He called this social pathology. When I visited him in 1943 to ask him about a possible career in social medicine he recommended me to read government statistical reports on mortality as "good bedside reading". A short while before, J B S Haldane, writing in the Daily Worker, had said:

"If the workers would read "The Registrar General's Decennial Supplement on Occupational Mortality" there would be a revolution tomorrow."

This report demonstrated the steep social class gradients for all causes of death combined and, most markedly, for tuberculosis and all respiratory disease.

The Interim Report of the Royal College of Physicians of London, 1943, recommended that every medical school should establish a department of social and preventive medicine. It made recommendations on how the subject should be taught and emphasised the importance of integrating it with clinical studies. $^{5}$ Other universities soon followed Oxford's example. Edinburgh appointed F A E Crew, $\dagger$ a professor of animal genetics, to a chair of public health and social medicine in 1944 and Birmingham appointed Tom McKeown, a research worker on air raid casualties, to the new chair of social medicine in 1945. Soon after, Trinity College, Dublin, appointed a professor of biochemistry, W J E Jessop, to its new chair of social medicine. These early appointments, which did not include anyone trained in public health, indicate that the universities were seeking candidates with experience and interests outside the traditional field of public health. London University was very slow to follow and did not create a chair of clinical epidemiology and social medicine until 1968. Walter Holland was the first occupant.

In the 1940s social medicine in the UK was mainly thought of in terms of the importance of social conditions in relation to clinical disease. Epidemiology was still considered by most doctors to be the study of epidemics of infectious fevers. The term was not used then as we use it today, to include the study of the distribution of non-communicable conditions.

\section{EPIDEMIOLOGICAL RESEARCH AND ITS EXTENSION TO NON-COMMUNICABLE DISEASE}

Austin Bradford Hill (1897-1991), professor of medical statistics at the London School of Hygiene and Tropical Medicine (LSHTM), and a remarkable group of research workers influenced by him (appendix 1), played an important part in the extension of epidemiology in the UK to non-communicable disease in the years after the end of the second world war.

†Aphorisms of F A E Crew: "The House of Commons is the pharmacy of Social Medicine," and "Man is the greatest pathogen known to man."
Richard Doll, working with Hill, embarked on his seminal research on cancer of the lung and smoking. J N (Jerry) Morris became director of the new Medical Research Council (MRC) Social Medicine Research Unit in 1948 and started the research that was to throw much light on the causation of coronary heart disease. Archie Cochrane was responsible for many important developments in epidemiological methods and knowledge. John Brotherston became the chief medical officer in Scotland and Donald Reid, deputy to Bradford Hill, carried out important research on the epidemiology of mental disorder and was influential in developing methods of epidemiological research.

By the end of the 1940s there were two main growing points in social medicine. Firstly, there were the new university departments that were creating courses in social medicine in the undergraduate medical curriculum and initiating epidemiological research. The staff of these departments consisted, typically, of the professor and a senior lecturer and one or two research assistants and often included a medical or psychiatric social worker. The courses were linked where possible to the clinical course. At the same time the department was probably embarking on research in the form of a medical social survey. The second important growing point, discussed above, was represented by the group of doctors at the LSHTM who, at the end of the 1940s, were starting important research in the field of non-communicable disease.

The Medical Research Council played a significant part in these developments by creating several research units that proved to be of great important in advancing epidemiology. In addition to Morris's Social Medicine Research Unit, 1948, it created the Pneumoconiosis Research Unit, 1945 (director, Charles Fletcher), the Statistical Research Unit, 1945 (first directed by Bradford Hill and then, in 1961, by Richard Doll) and the Epidemiological Unit, South Wales, 1962 (director, Archie Cochrane).

\section{CONTACTS IN THE USA AND THE CREATION OF PROFESSIONAL ASSOCIATIONS FOR SOCIAL MEDICINE AND EPIDEMIOLOGY}

In the 1950s some of us went to the USA for further experience. In the period of McCarthyism we were not always welcome. When the immigration officer at New York read my introductory letter from the MRC stating that the object of my visit was "to study the teaching of social medicine in the USA" he said, with some emphasis, "We don't want any of that filth here."

At the New York Hospital I met a young physician, Harold Willard, who had become interested in what happened to his patients after they left hospital. We had both done some research and teaching on the social aspects of clinical medicine but found that we were ignorant about what was going on in academic social medicine and epidemiology elsewhere, even in our own countries. To remedy this we decided to organise an International Corresponding Club (ICC) for those working in this field. Membership was restricted to medically qualified non-heads of the appropriate university departments or workers in research units, and we exchanged information by way of a twice yearly bulletin. (We excluded heads of departments because we thought that they would cramp our style.) The purpose of the club, as stated in the first number, was:

\section{"To facilitate communication between medical men and women engaged in teaching or research in preventive and social medicine throughout the world."}

The first number of the bulletin appeared in January 1955 and contained contributions from 26 correspondents in nine countries. We soon found that writing communications was 


\begin{tabular}{lll} 
Table 1 & There were five sessions & \\
\hline 1 & $\begin{array}{l}\text { Epidemiology as a Research Tool } \\
\text { Some Comments on Recent Criticism of Prospective and Retrospective }\end{array}$ & J R Morris \\
3 & $\begin{array}{l}\text { Studies } \\
\text { The Teaching of Social and Preventive Medicine to Medical }\end{array}$ & Alex Mair, Maurice Backett \\
4 & $\begin{array}{l}\text { Undergraduates } \\
\text { Is there a need for a British Scientific Society of Preventive and Social }\end{array}$ & John Pemberton, Alice Stewart \\
5 & $\begin{array}{l}\text { Medicine? } \\
\text { International Aspects }\end{array}$ & A Querido (Amsterdam), Gurney Clark (New York) \\
\hline
\end{tabular}

not enough and decided to organise a meeting of correspondents in London. The Ciba Foundation agreed to support a small meeting and this took place at the Foundation's headquarters at 41 Portland Place, London, on 30 June and 1 July 1956. Twenty correspondents and nine invited visitors attended (appendix 2). By this time we had abolished the rule limiting membership to non-heads of departments because several of our members had become heads.

There were five sessions (see table 1).

\section{THE FOUNDING OF THE SOCIETY FOR SOCIAL MEDICINE}

There was an animated discussion on Item 4 at the end of which the chairman, James Mackintosh (Professor of Public Health at the LSHTM), expressed the conclusion of the meeting in the following words:

"It was agreed in principle that a British Society of Preventive and Social Medicine should be formed with the following essential features: It should be a wholly independent society. Its main object should be the advancement of academic social medicine, primarily in the research field. The society should normally hold its meetings at various academic and research institutes with which its members are professionally associated. The place of meeting should be selected for its scientific interest rather than for accessibility. The society should approach the governing body of the Journal of Preventive and Social Medicine with a view to forming a close association. The membership of the Society should be limited by certain criteria which will be gradually established as it develops. In the intial stages however, membership would be offered to all who hold academic and research positions in this field. It was agreed that the operative basis of the society should be in the nature of an annual conference lasting perhaps two or three days and, according to need, one other meeting during the year."

When James Mackintosh put this motion to the meeting Jerry Jessop, Professor of Social Medicine at Trinity College Dublin, called out from the back of the room, "Do you mind omitting the world British?" After a moment of stunned silence there was a general murmur of "Agreed." So the new society became the Society for Social Medicine and it has enjoyed and benefited from its inclusion of members from the Republic of Ireland ever since. A steering committee of five was elected at the meeting.

Chairman, W J E Jessop

Hon Secretary, Alice Stewart

Treasurer, John Pemberton

Other committee members: John Brotherston, Tom McKeown The steering committee had been given powers of cooption and on the following afternoon it coopted Richard Doll.

At the final session of the London meeting a discussion on International Aspects took place and it was decided to accept the invitation of Professor A Querido to hold an international study group in the Netherlands in 1957. This meeting was held as planned and became the first international scientific meeting of the organisation, which later became the International
Epidemiological Association, the IEA. The first scientific meeting of the Society for Social Medicine took place in Birmingham at the end of September 1957 and that of the IEA in Noordwijk, on the Dutch coast, at the beginning of the same month.

From the beginning membership of the Society for Social Medicine was offered to those, not necessarily medically qualified, who held academic or research posts in social medicine or related subjects. Non-medical members, such as Margot Jefferys and Ann Cartwright, contributed much to the society. Up to this time sociologists had had very little, if any, input into medical education and research. In attracting just a few into academic departments of social medicine and obtaining their cooperation in epidemiological research, the important relation of sociology to medicine was demonstrated. This relation has been explored fully by a number of American and British writers in Social Medicine and Medical Sociology in the Twentieth Century edited by Dorothy Porter. ${ }^{6}$

Statisticians were also welcomed to membership of the society and appointed to academic departments of social medicine and research units. They have made great contributions to epidemiology and indeed to all medical research. Medical officers of health and their deputies or assistants were only offered membership if they had carried out research in social medicine. It was felt that if membership had been thrown open to all who were working in the field of public health that the society might have become unbalanced in that direction. By 1973 the conditions of membership had been widened further and simply stated that "Membership of the Society shall be open to all those who contribution to the objectives of the Society."

When the society was founded there were already some distinguished clinicians who had recognised the important contributions that social medicine and epidemiology could make, and was making, to their branches of medicine. These included George Pickering, Regius Professor of Medicine in Oxford, Melville Arnott, Professor of Medicine in Birmingham, and Aubrey Lewis, Professor of Psychiatry and Head of the Maudsley Institute. Will Pickles, the Yorkshire general practitioner who had carried out some remarkable research on infectious diseases in his Wensleydale practice and later became the first president of the College (later Royal College) of General Practitioners, was a founder member. Other early members, leaders in their own fields, included Lancelot Hogben, Lionel Penrose, and Jack Tizard. The strength and influence of the society from an early stage was probably increased by having distinguished representatives from a variety of disciplines other than medicine.

The first annual scientific meeting of the society was organised by the Department of Social Medicine of Birmingham University with Tom McKeown in the chair. The second was in Trinity College, Dublin, with W J E (Jerry) Jessop, in the chair. Subsequent meetings are listed in appendix 3.

\section{LINK WITH THE BRITISH JOURNAL OF PREVENTIVE AND SOCIAL MEDICINE}

Formal links between the Society and the British Journal of Preventive and Social Medicine (later to become the Journal of Epidemiology and Community Health), were established in 1959 and 

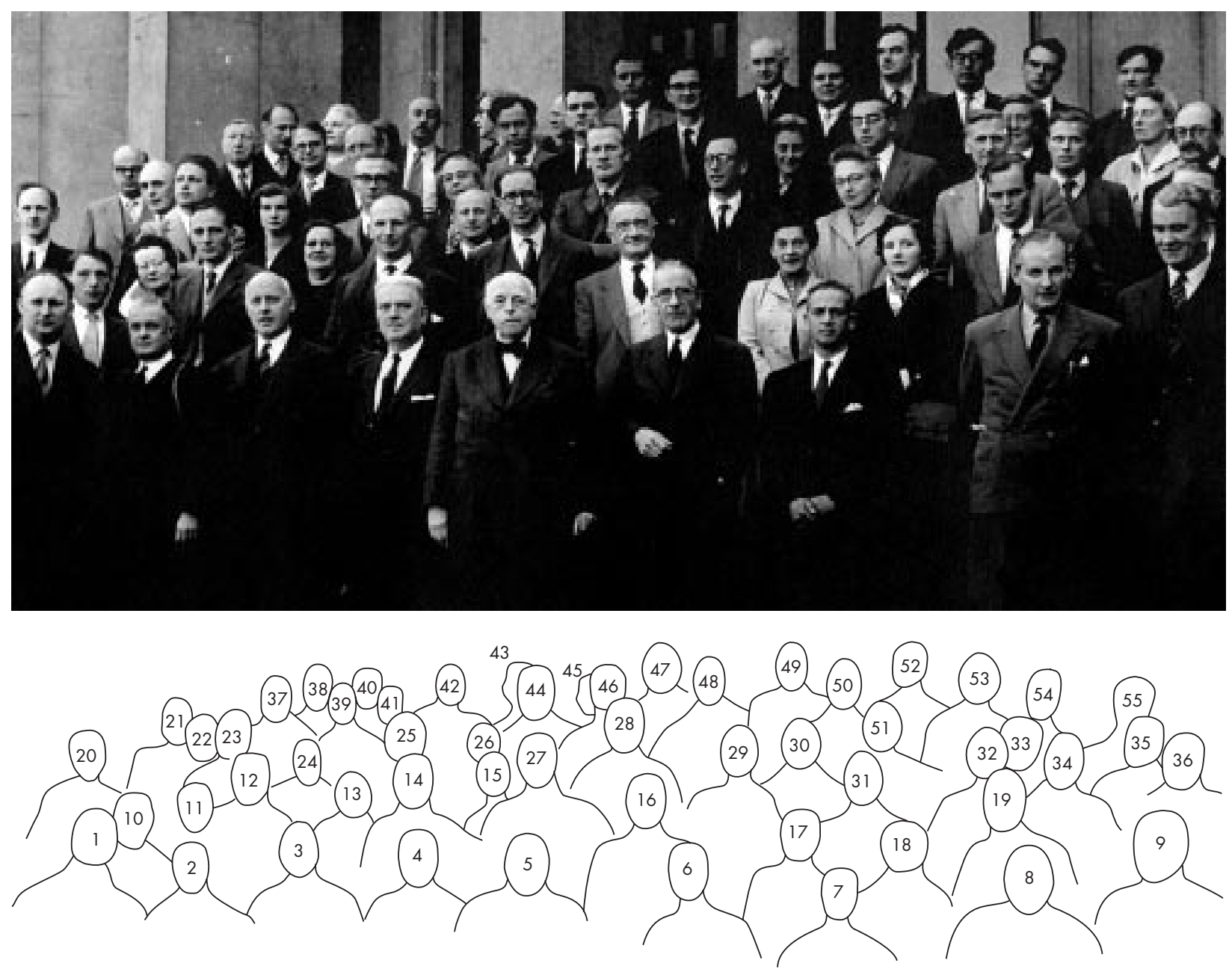

Figure 1 Society for Social Medicine. Those present at the second annual meeting, Trinity College, Dublin, 1958 (readers are invited to identify those whose names are missing). Key to group photograph: (1) Tom Murphy, (2) ?, (3) W J E (Jerry) Jessop, (4) ?, (5) Will Pickles, (6) ?, (7) J A Montoya, (8) Alex Mair, (9) Horace Joules, (10) Roy Acheson, (11) ?, (12) John Pemberton, (13) Victoria Coffey, (14) Robert Sutherland, (15) ?, (16) Archie Cochrane, (17) ?, (18) ?, (19) Christopher Wood, (20) ?, (21) Maurice Backett, (22) ?, (23) ?, (24) ?, (25) ?, (26) Muriel Newhouse, (27) lan Higgins, (28) Jim Kilpatrick, (29) ?, (30) Margot Jefferys, (31) Joan Faulkner, (32) Richard Doll, (33) Ann Cartwright, (34)?, (35) ? (36) Eric Cheeseman, (37) ?, (38) J W B Douglas, (39) Robert Wofinden, (40) ?, (41) ? , (42) Aubrey Lewis, (43) ? , (44) Robert Hitchens, (45) Corbett McDonald, (46) ?, (47) Alwyn Smith, (48) Austin Heady, (49) ?, (50) ?, (51) ?, (52) John Lee, (53) Ken Newall, (54) lan Leck, (55) George Knox.

two representatives of the society were added to the editorial board. Titles of papers to be read at the annual scientific meetings were published in the journal, and in 1962 fuller accounts of the society's proceedings and abstracts of papers given at the scientific meetings were included.

\section{THE LATER HISTORY OF THE SOCIETY}

Ian Leck, in writing about the Society in the years 1956-96, commented on the great expansion in the number of papers given at the annual scientific meetings over this period from 16 to 77 . He also noted that just over half were concerned with health services research in 1996, whereas at the early meetings the great majority of the papers dealt with the epidemiology of specific disorders.

Further details about the society and the development of social medicine in the UK up to the 1970s are given by several contributors in the book edited by D Porter. ${ }^{6}$

\section{ACKNOWLEDGEMENT}

I would like to thank Mr John Eyers, deputy librarian at the London School of Hygiene and Tropical Medicine, for his help with appendix 1. Funding: none.

Conflicts of interests: none.

\section{APPENDIX 1}

Some of those who were at the London School of Hygiene and Tropical Medicine after the end of the 1939-45 war who worked with, or were influenced by, Bradford Hill and who made significant contributions to our knowledge of the epidemiology of non-communicable disease.

Richard Doll

Donald Reid

Archie Cochrane, DPH London 1946

John Brotherston, DPH London 1947

John Knowelden, DPH London 1947

J N (Jerry) Morris, DPH London 1947

Richard Schilling, DPH London 1947

\section{APPENDIX 2}

Those who attended the meeting in London in June 1956 at which the Society for Social Medicine was founded.

Members of the International Corresponding Club:

Dr Ian McCallum, Durham University

Dr C R Lowe, Birmingham University

Dr James Hislop, Cambridge Unviersity

Dr A L Cochrane, Pneumoconiosis Research Unit

Dr Maurice Backett, Queen's University, Belfast

Dr Alice Stewart, Oxford University

Dr Richard Scott, Edinburgh University

Dr Robert Sutherland, Leeds University 
Dr R C Wolfinden, Bristol University Prof Alex Mair, Dundee University Dr John Pemberton, Sheffield University Prof A Querido, Amsterdam University Dr Richard Doll, London School of Hygiene Prof Robert Cruickshank, St Mary's Hospital, London Dr John Lee, Social Medicine Research Unit, London Hospital Dr R N Hitchens, Welsh National School of Medicine Professor John Brotherston, University of Edinburgh Professor W J E Jessop,Trinity College, Dublin Professor Gurney Clark, Columbia University, New York
Visitors:

Prof James Mackintosh, London School of Hygiene

Dr J N Morris, Social Medicine Research Unit, London Hospital Prof W Hobson, Sheffield University

Prof Tom McKeown, Birmingham University

Prof F Grundy, Welsh National School of Medicine

Dr Alex Robertson, London School of Hygiene

Prof A Stevenson, Queen's University, Belfast

Prof Tom Murphy, University College, Dublin

Prof E K Cruickshank, University College of the West Indies

\begin{tabular}{|c|c|c|}
\hline \multicolumn{3}{|c|}{$\begin{array}{l}\text { APPENDIX } 3 \text { Venues of the annual scientific meetings of the Society for Socia } \\
\text { Medicine from its foundation }\end{array}$} \\
\hline Number & Year & \\
\hline 1 & 1957 & University of Birmingham \\
\hline 2 & 1958 & Trinity College, Dublin \\
\hline 3 & 1959 & Dundee \\
\hline 4 & 1960 & St Hugh's College, Oxford \\
\hline 5 & 1961 & University of London \\
\hline 6 & 1962 & Welsh National School of Medicine, Cardiff \\
\hline 7 & 1963 & Queen's University, Belfast \\
\hline 8 & 1964 & University of Aberdeen \\
\hline 9 & 1965 & University of Sheffield \\
\hline 10 & 1966 & University of Edinburgh \\
\hline 11 & 1967 & University of Manchester \\
\hline 12 & 1968 & Imperial College, London \\
\hline 13 & 1969 & University of Glasgow \\
\hline 14 & 1970 & Royal Victoria Infirmary, Newcastle upon Tyne \\
\hline 15 & 1971 & Trinity College, Dublin \\
\hline 16 & 1972 & Radcliffe Infirmary, Oxford \\
\hline 17 & 1973 & University of Southampton \\
\hline 18 & 1974 & Welsh National School of Medicine, Cardiff \\
\hline 19 & 1975 & University of Kent, Canterbury \\
\hline 20 & 1976 & Imperial College, London \\
\hline 21 & 1977 & University of Birmingham \\
\hline 22 & 1978 & University of Leeds \\
\hline 23 & 1979 & University of Bristol \\
\hline 24 & 1980 & Churchill College, Cambridge \\
\hline 25 & 1981 & Teeside Polytechnic, Middlesborough \\
\hline 26 & 1982 & University of Aberdeen \\
\hline 27 & 1983 & University of Sheffield \\
\hline 28 & 1984 & University of Oxford \\
\hline 29 & 1985 & University of Liverpool \\
\hline 30 & 1986 & University of Leicester \\
\hline 31 & 1987 & University of Dublin \\
\hline 32 & 1988 & University of Newcastle \\
\hline 33 & 1989 & University of Manchester \\
\hline 34 & 1990 & University of Glasgow \\
\hline 35 & 1991 & University of Southampton \\
\hline 36 & 1992 & University of Nottingham \\
\hline 37 & 1993 & University of Cambridge \\
\hline 38 & 1994 & University of Leeds \\
\hline 39 & 1995 & Royal Holloway University (University of London) \\
\hline 40 & 1996 & University of Dundee \\
\hline 41 & 1997 & University of York \\
\hline 42 & 1998 & Welsh College of Medicine, Cardiff \\
\hline 43 & 1999 & University of Sheffield \\
\hline
\end{tabular}

\section{REFERENCES}

1 Orr J B. Food, health and income. London: Macmillan, 1936.

2 Pemberton J. Malnutrition in England. University College Hospital Magazine 1934;191:53-9.

3 Committee against Malnutrition. [Medical News]. Lancet 1938;i:527.

4 Stewart J. The battle for health. A political history of the Socialist Medical Association, 1930-51. Aldershot: Ashgate Publishing Limited, 1999.
5 Royal College of Physicians of London. Social and Preventive Medicine Committee: Interim Report. London: Royal College of Physicians of London, October 1943

6 Porter D, ed. Social medicine and medical sociology in the Twentieth century. Amsterdam: Rodopi BV, 1997:202.

7 Leck I. The Society for Social Medicine; 1956-1996. J Epidemio Community Health 1996;50:177. 